\title{
Microbial Cellulose Production from Bacteria Isolated from Rotten Fruit
}

\author{
B. E. Rangaswamy, ${ }^{1}$ K. P. Vanitha, ${ }^{1}$ and Basavaraj S. Hungund ${ }^{2}$ \\ ${ }^{1}$ Department of Biotechnology, Bapuji Institute of Engineering and Technology, Davangere 577004, India \\ ${ }^{2}$ Department of Biotechnology, B.V.B. College of Engineering and Technology, Hubballi 580031, India
}

Correspondence should be addressed to K. P. Vanitha; vanidwani@gmail.com

Received 31 July 2015; Accepted 4 November 2015

Academic Editor: Valéria C. Santos-Ebinuma

Copyright (c) 2015 B. E. Rangaswamy et al. This is an open access article distributed under the Creative Commons Attribution License, which permits unrestricted use, distribution, and reproduction in any medium, provided the original work is properly cited.

\begin{abstract}
Microbial cellulose, an exopolysaccharide produced by bacteria, has unique structural and mechanical properties and is highly pure compared to plant cellulose. Present study represents isolation, identification, and screening of cellulose producing bacteria and further process optimization. Isolation of thirty cellulose producers was carried out from natural sources like rotten fruits and rotten vegetables. The bacterial isolates obtained from rotten pomegranate, rotten sweet potato, and rotten potato were identified as Gluconacetobacter sp. RV28, Enterobacter sp. RV11, and Pseudomonas sp. RV14 through morphological and biochemical analysis. Optimization studies were conducted for process parameters like inoculum density, temperature, $\mathrm{pH}$, agitation, and carbon and nitrogen sources using Gluconacetobacter sp. RV28. The strain produced $4.7 \mathrm{~g} / \mathrm{L}$ of cellulose at optimum growth conditions of temperature $\left(30^{\circ} \mathrm{C}\right), \mathrm{pH}(6.0)$, sucrose $(2 \%)$, peptone $(0.5 \%)$, and inoculum density $(5 \%)$. Characterization of microbial cellulose was done by scanning electron microscopy (SEM).
\end{abstract}

\section{Introduction}

Microbial cellulose is an extracellular polysaccharide produced by some bacterial genera such as Acetobacter, Agrobacterium, Gluconacetobacter, Rhizobium, Achromobacter, Alcaligenes, Aerobacter, Azotobacter, Rhizobium, Salmonella, Escherichia, and Sarcina. It represents alternative to plantderived cellulose for some specialty applications in the medical field and food and other industries $[1,2]$. Members of Gluconacetobacter genus like Gluconacetobacter xylinus and Gluconacetobacter hansenii are the most potential producers compared to other strains. The microbial cellulose (MC) produced by Acetobacter strain can be used as diet food and to produce new materials for high performance speaker diaphragms, medical pads, makeup pads, paint thickeners, and artificial skin because of the unique properties of this cellulose distinct from those of plant cellulose $[3,4]$. The microbial cellulose has a large specific surface area, higher water retention value, moldability, and high tensile strength compared with plant cellulose. Microbial cellulose can be produced by culturing a strain of Acetobacter xylinum, reclassified as the genus Gluconacetobacter, which is typically found on decaying fruits, vegetables, vinegar, fruit juices, and alcoholic beverages. The bacteria of this family convert ethanol to acetic acid. In the earlier studies, several attempts were made to isolate Gluconacetobacter sp. from fruits [5], flowers, fermented foods [6], beverages [7], and vinegar. In the current study, we aimed to isolate cellulose producing bacteria from rotten fruits and rotten vegetables. The cellulose producing strains were identified by morphological and biochemical characterization. In fact, to achieve high yield cellulose production, the culture conditions have a crucial influence, in particular factors such as carbon source, nitrogen source, temperature, $\mathrm{pH}$, and agitation $[1,8]$. In this work, we have investigated the influence of the culture conditions on cellulose production by Gluconacetobacter sp. RV28 isolated from rotten pomegranate. The effects of carbon source, nitrogen source, $\mathrm{pH}$, temperature, and inoculum density were investigated. The cellulose produced from Gluconacetobacter sp. RV28 was characterized by scanning electron microscopy (SEM). 


\section{Materials and Methods}

2.1. Collection of Samples. Samples of rotten fruits (apple, banana, guava, grape, mango, orange, pomegranate, and sweet lime) and rotten vegetables (potato, ladies finger, onion, ridge guard, sweet potato, carrot, brinjal, and tomato) were collected from various places of Shimoga, Davangere, and Haveri (Karnataka, India). All the samples were stored in normal saline at $4^{\circ} \mathrm{C}$ till further reference.

2.2. Chemicals and Reagents. All the media ingredients and biochemical test kits (KB001 and KB009) were procured from Hi-Media, Mumbai, India. Fluorescent brightener 28 was purchased from Sigma-Aldrich.

2.3. Isolation of Cellulose Producing Bacteria. A known weight $(1 \mathrm{~g})$ of each sample was taken separately and inoculated into $9 \mathrm{~mL}$ saline $(0.9 \%)$ and serially diluted up to $10^{-6}$ dilution; further pour plate method was done using standard Hestrin-Schramm agar (D-glucose $20 \mathrm{~g} / \mathrm{L}$, yeast extract $5 \mathrm{~g} / \mathrm{L}$, peptone $5 \mathrm{~g} / \mathrm{L}$, disodium phosphate $2.7 \mathrm{~g} / \mathrm{L}$, citric acid $1.15 \mathrm{~g} / \mathrm{L}$, and agar $15 \mathrm{~g} / \mathrm{L}$ ) and incubated for $48 \mathrm{~h}$ at $30^{\circ} \mathrm{C}$. One loopful of each isolate was inoculated into $9 \mathrm{~mL}$ of Hestrin-Schramm media (D-glucose $20 \mathrm{~g} / \mathrm{L}$, yeast extract $5 \mathrm{~g} / \mathrm{L}$, peptone $5 \mathrm{~g} / \mathrm{L}$, disodium phosphate $2.7 \mathrm{~g} / \mathrm{L}$, and citric acid $1.15 \mathrm{~g} / \mathrm{L}$ ). These tubes were incubated statically at $30^{\circ} \mathrm{C}$ for 7 days. After incubation, the tubes with white pellicle covering the surface of liquid medium were selected.

2.4. Screening of Cellulose Producer. All the flasks were observed for pellicle formation at air liquid interface. Those flasks with pellicle growth were selected and purified the culture by repeated streaking on HS agar plates to obtain isolated colonies. Each distinct isolate was inoculated on screening media, that is, HS agar with fluorescent brightener dye $(0.02 \% \mathrm{w} / \mathrm{v})$ and antifungal agent cycloheximide incubated at $30^{\circ} \mathrm{C}$ for 3 days. The fluorescent dye binds to the cellulose content in the organism. Cellulose producing bacterial colonies fluoresces when observed under UV light. So the fluorescent colonies were selected as cellulose producers [2].

2.5. Identification of Cellulose Producer. Bacterial isolates were identified by performing gram staining, colony morphology, motility test, and biochemical characteristics followed by carbohydrate fermentation test [9]. The strain was characterized for its biochemical properties using rapid biochemical test kit KB002 and KB009 (Hi-Media, India) according to manufactures instructions.

2.6. Detection of Cellulose Production and Quantification. The pellicle formed at the air-liquid interface of broth was treated with $1 \mathrm{~N} \mathrm{NaOH}$ at $80^{\circ} \mathrm{C}$ for 15 minutes and then washed for about 3-4 times with distilled water; then, pellicle was neutralized with $4 \%$ acetic acid and again washed for 3-4 times with distilled water and dried in hot air oven at $60^{\circ} \mathrm{C}$ overnight. Then, the dry weight of cellulose was determined. Cellulose producing isolates were selected and inoculated

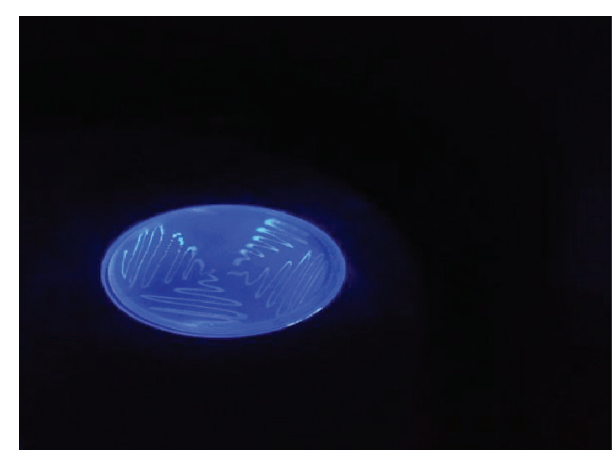

FIGURE 1: Fluorescent colony of Gluconacetobacter sp. RV28 under UV light.

into Hestrin-Schramm media at $30^{\circ} \mathrm{C}$ and incubated for 14 days. Dry weight of cellulose was quantified by using similar method as mentioned.

2.7. Optimization of Culture Conditions. To optimize cellulose production by Gluconacetobacter sp. RV28, different physiological and nutritional parameters were studied such as $\mathrm{pH}$, temperature, incubation period, agitation, carbon, and nitrogen sources. The experiments for optimization were carried out in triplicate and the standard error graphs were plotted. All the experiments were carried out in static condition of growth.

2.8. Scanning Electron Microscopy (SEM). The ultrafine structure of bacterial cellulose fibrils was characterized using scanning electron microscope (SEM model: JEOL Model JSM, 6390LV). Thin layers of freeze-dried cellulose were gold coated using ion sputter and coated samples were viewed and photographed at $20 \mathrm{k}$.

\section{Result}

3.1. Isolation and Screening of Cellulose Producing Bacteria. In the present study, thirty-six bacterial isolates were obtained from different natural sources which are found to produce cellulose. Those isolates showed fluorescence when observing their growth in screening medium under UV light. In screening media fluorescent dye binds to the cellulose content in the organism. Thus, cellulose producing bacterial colonies fluoresces when observed under UV light. So the fluorescent colonies were selected as cellulose producers (Figure 1). The isolates which obtained RV28 (rotten pomegranate), RV11 (rotten sweet potato), and RV14 (rotten potato) showed better cellulose production compared to other isolates.

3.2. Identification of Cellulose Producer. Identification of the strain was based on cultural characterization, biochemical characterization, and carbohydrate fermentation tests and results were tabulated (Tables 1, 2, and 3) (Figure 2). On the basis of biochemical characteristics, bacterial strains were identified as Gluconacetobacter sp. RV28, Pseudomonas sp. RV14, and Enterobacter sp. RV11. 
TABLE 1: Biochemical characterization for the isolates.

\begin{tabular}{lccc}
\hline Characteristics test & Enterobacter sp. & Gluconacetobacter sp. & \multicolumn{2}{c}{ Pseudomonas sp. } \\
& RV11 & RV28 & Gram negative rods \\
Gram reaction & Gram negative rods & Gram negative rods & Motile \\
Motility & Motile & + & + \\
Cellulose production & + & 3.1 & 1.2 \\
Cellulose yield g/L & 1.9 & + & + \\
Catalase & + & - & - \\
Oxidase & - & - & - \\
Citrate utilization & + & - & - \\
Indole test & + & - & - \\
Methyl red & + & - & - \\
Voges-Proskauer & - & - & - \\
Urease & + & & - \\
$\mathrm{H}_{2}$ S production & + & - & - \\
\hline
\end{tabular}

TABLE 2: Carbohydrate fermentation test.

\begin{tabular}{|c|c|c|c|}
\hline Carbon source & $\begin{array}{c}\text { Enterobacter sp. } \\
\text { RV11 }\end{array}$ & $\begin{array}{c}\text { Gluconacetobacter sp. } \\
\text { RV28 }\end{array}$ & $\begin{array}{c}\text { Pseudomonas sp. } \\
\text { RV14 }\end{array}$ \\
\hline Glucose & + & + & + \\
\hline Adonitol & - & + & + \\
\hline Arabinose & + & + & + \\
\hline Lactose & - & + & + \\
\hline Sorbitol & + & + & + \\
\hline Mannitol & + & + & + \\
\hline Rhamnose & + & + & + \\
\hline Sucrose & + & + & + \\
\hline Dextrose & + & + & + \\
\hline Xylose & + & - & + \\
\hline Maltose & + & + & + \\
\hline Fructose & + & + & + \\
\hline Galactose & + & + & + \\
\hline Raffinose & + & - & + \\
\hline Trehalose & + & - & + \\
\hline Melibiose & + & - & + \\
\hline L-Arabinose & + & + & + \\
\hline Mannose & + & + & + \\
\hline Sodium gluconate & + & - & - \\
\hline Glycerol & + & + & + \\
\hline Inositol & + & + & - \\
\hline Erythritol & + & + & - \\
\hline$\alpha$-Methyl-D-glucoside & + & + & - \\
\hline Xylitol & + & + & + \\
\hline ONPG & - & - & - \\
\hline Esculin hydrolysis & - & - & + \\
\hline Malonate utilization & - & - & + \\
\hline Sorbose & + & + & + \\
\hline
\end{tabular}

3.3. Detection of Cellulose. The strain Gluconacetobacter sp. RV28, Pseudomonas sp. RV14, and Enterobacter sp. RV11 were observed to form pellicle at air liquid interphase (Figure 3). The pellicle was treated with alkali at $80^{\circ} \mathrm{C}$ followed by washing with distilled water. The cellulose is resistant to this treatment and remains undissolved and is accepted as pure cellulose. Yield is quantified for each isolate and presented in Table 4. 

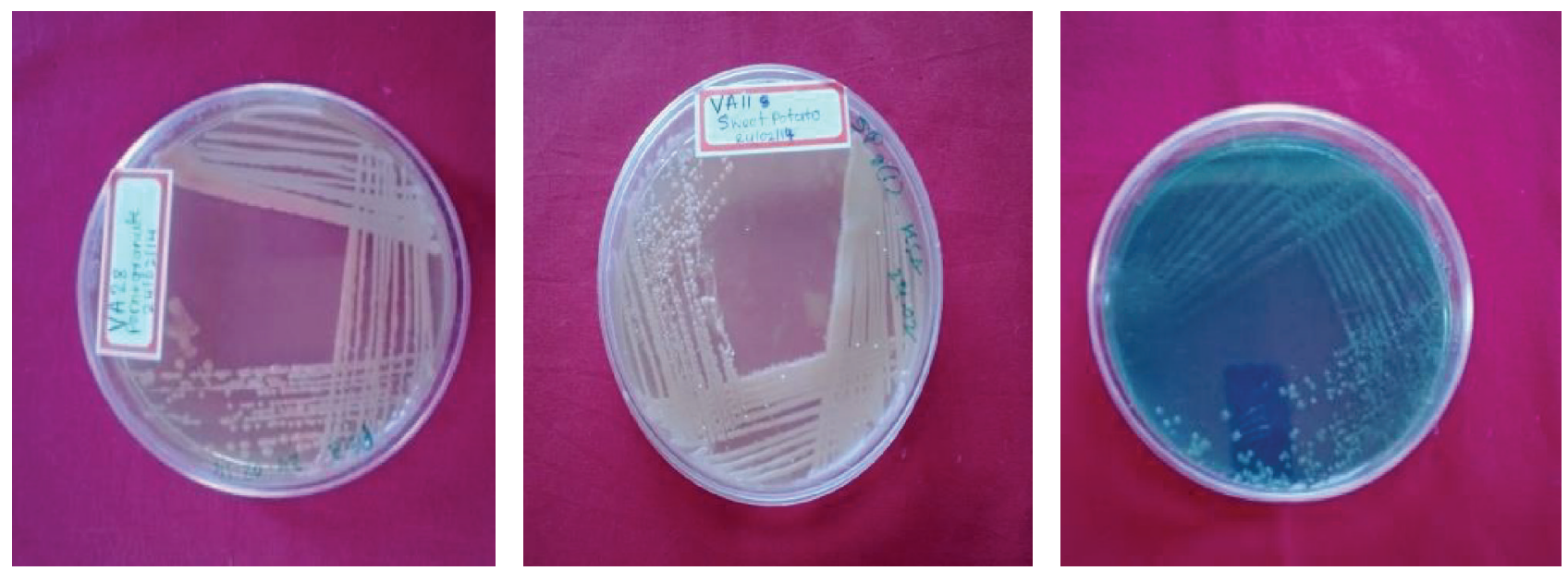

FIGURE 2: Colony morphology of Gluconacetobacter sp., Enterobacter sp., and Pseudomonas sp.

TABLE 3: Cultural characterization of Gluconacetobacter sp. RV28.

\begin{tabular}{lc}
\hline Colony morphology & Gluconacetobacter sp. RV28 \\
\hline Configuration & Round \\
Margin & Entire \\
Elevation & Raised \\
Surface & Smooth, mucoid \\
Color & Pink \\
Opacity & Translucent \\
Motility & Motile \\
Cell shape & Rod \\
Spore formation & Negative \\
\hline
\end{tabular}

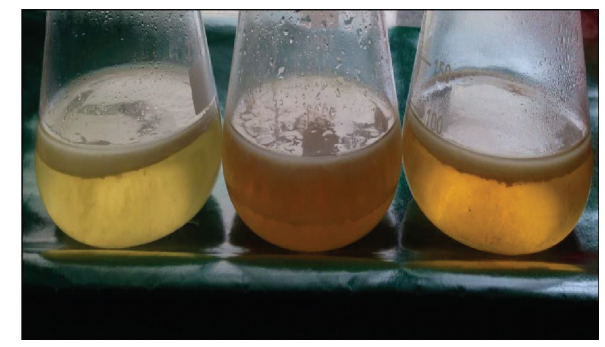

FIgure 3: Pellicle formed at air liquid interface by the isolates Gluconacetobacter sp., Enterobacter sp., and Pseudomonas sp.

3.4. Scanning Electron Microscope. The ultrafine structure of bacteria cellulose constituted by cellulose nanofibre structure magnified at 5000 at $20 \mathrm{kV}$. Cellulose microfibrils and nanofibres were evidenced through SEM studies (Figure 4).

\subsection{Effect of Inoculum Density on Cellulose Production.} The inoculum volume plays an important role in cellulose production. To study the effect of inoculum size of Gluconacetobacter sp. RV28 inoculum size ranging from $1 \%$ to $10 \%(\mathrm{v} / \mathrm{v})$ was examined for cellulose production. The results are presented in Figure 5. The cellulose production was observed in all inoculum size tested but lower and higher

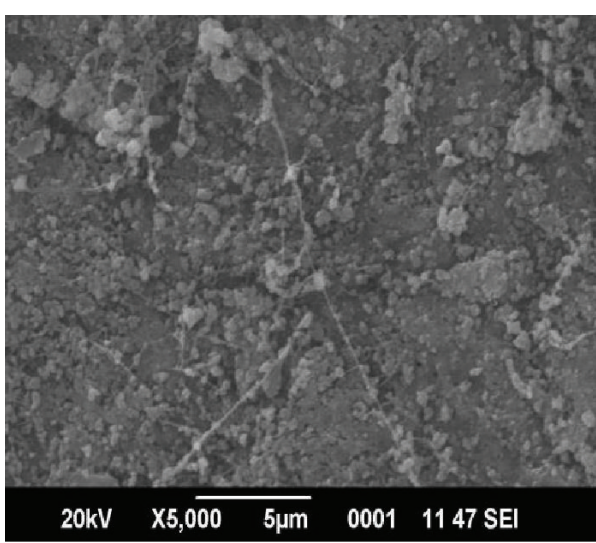

FIGURE 4: SEM image of cellulose produced by Gluconacetobacter $\mathrm{sp}$.

values than $5 \%$ inoculum showed there is a decrease in cellulose production. By this experiment, we can conclude that $5 \%$ inoculum size is optimum for cellulose production and achieved $2.5 \mathrm{~g} / \mathrm{L}$ yield compared to other inoculum sizes.

3.6. Effect of $\mathrm{pH}$ on Cellulose Production. The $\mathrm{pH}$ plays an important role in cell growth and cellulose production. To study the effect of $\mathrm{pH}$ on cellulose production, the organism was grown in medium with $\mathrm{pH}$ value ranging from 2 to 10 . The results are presented in Figure 6. The cellulose production was observed in all $\mathrm{pH}$ values tested but $\mathrm{pH}$ range 3-7 showed better production compared to other $\mathrm{pH}$ values. By this investigation, we can observe that $\mathrm{pH} 6$ is optimum for cellulose production and achieved $2.1 \mathrm{~g} / \mathrm{L}$ which is maximum yield compared to other $\mathrm{pH}$ values.

3.7. Effect of Temperature on Cellulose Production. The temperature plays very important role as it directly affects cell growth and cellulose production. To study the effect of temperature on cellulose production by Gluconacetobacter $\mathrm{sp}$. RV28 temperature, range from 20 to $45^{\circ} \mathrm{C}$ was examined. 
TABLE 4: Screening of isolates for cellulose production (yield in $\mathrm{g} / \mathrm{L}$ ).

\begin{tabular}{|c|c|c|c|c|c|}
\hline Sample number & Source & Isolate code & Gram reaction & Fluorescence & Yield g/L \\
\hline 1 & Apple & RV01 & Gram negative & + & 0.91 \\
\hline 2 & Sweet lime & RV02 & Gram negative & + & 1.0 \\
\hline 3 & Apple & RV06 & Gram negative & + & 0.96 \\
\hline 4 & Apple & RV03 & Gram negative & + & 0.51 \\
\hline 5 & Apple & RV04 & Gram negative & + & 1.1 \\
\hline 6 & Apple & RV05 & Gram negative & + & 0.81 \\
\hline 7 & Ladies finger & RV20 & Gram negative & + & 0.75 \\
\hline 8 & Ladies finger & RV21 & Gram negative & + & 0.09 \\
\hline 9 & Ladies finger & RV22 & Gram negative & + & 0.22 \\
\hline 10 & Ladies finger & RV23 & Gram negative & + & 0.66 \\
\hline 11 & Ladies finger & RV24 & Gram negative & + & 0.08 \\
\hline 12 & Ridge guard & RV25 & Gram negative & + & 0.08 \\
\hline 13 & Onion & RV10 & Gram negative & + & 0.01 \\
\hline 14 & Sweet potato & RV11 & Gram negative & + & 1.9 \\
\hline 15 & Sweet potato & RV13 & Gram negative & + & 0.89 \\
\hline 17 & Sweet potato & RV16 & Gram negative & + & 1 \\
\hline 18 & Pomegranate 1 & RV26 & Gram negative & + & 1.1 \\
\hline 19 & Pomegranate 2 & RV27 & Gram negative & + & 0.97 \\
\hline 20 & Pomegranate 3 & RV28 & Gram negative & + & 3.1 \\
\hline 21 & Apple & RV7 & Gram negative & + & 0.9 \\
\hline 22 & Potato & RV14 & Gram negative & + & 1.2 \\
\hline 23 & Sweet lime 1 & RV30 & Gram negative & + & 0.9 \\
\hline 24 & Sweet lime la & RV31 & Gram negative & + & 1 \\
\hline 25 & Sweet lime $1 \mathrm{~b}$ & RV32 & Gram negative & + & 0.1 \\
\hline 26 & Grape 1 & RV33 & Gram negative & + & 0.9 \\
\hline 27 & Grape 2 & RV34 & Gram negative & + & 0.7 \\
\hline 28 & Sweet lime 1c & RV35 & Gram negative & + & 0.3 \\
\hline 29 & Sweet potato & RV36 & Gram negative & + & 0.2 \\
\hline 30 & Sweet potato & RV37 & Gram negative & + & 0.9 \\
\hline
\end{tabular}

The results indicated that temperatures $28-30^{\circ} \mathrm{C}$ favoured maximum cellulose production $1.99-2.31 \mathrm{~g} / \mathrm{L}$; the results are presented in Figure 7. The cellulose production was least at $37^{\circ} \mathrm{C}$ and cellulose production was not observed in the range of 40 and $45^{\circ} \mathrm{C}$. By this investigation, we can conclude that optimum temperature for cellulose production is $28-30^{\circ} \mathrm{C}$.

3.8. Effect of Carbon Source on Cellulose Production. The carbon is a sole source for cellulose production and cell growth. To study the effect of carbon source on cellulose production, carbon sources like maltose, mannitol, mannose, sucrose, lactose, glucose, and fructose were supplemented at $2 \%(\mathrm{w} / \mathrm{v})$ in standard Hestrin-Schramm medium. The results are presented in Figure 8; the strain utilized all carbon sources tested and least percent was from lactose. The maximum cellulose production was observed in sucrose followed by mannitol giving cellulose yield of $1.58-2.35 \mathrm{~g} / \mathrm{L}$.

3.9. Effect of Nitrogen on Cellulose Production. The nitrogen source is required for cell growth and cellulose production. To study the effect of nitrogen source on cellulose production, the nitrogen sources like peptone, ammonium nitrate, ammonium chloride, and ammonium sulphate were supplemented at $0.5 \%(\mathrm{w} / \mathrm{v})$ instead of peptone in standard medium. The results are presented in Figure 9. The maximum cellulose production was observed with peptone which gave cellulose yield of $2.15 \mathrm{~g} / \mathrm{L}$. By this investigation, we can conclude that good nitrogen source for cellulose production is peptone.

\section{Discussion}

Most of the earlier studies describe cellulose production by culturing a strain of Acetobacter xylinum, reclassified as the genus Gluconacetobacter, which is typically found on decaying fruits, vegetables, vinegar, fruit juices, and alcoholic beverages. The members of this family convert ethanol to acetic acid. Several attempts have been made to isolate Gluconacetobacter sp. from fruits [5], flowers, fermented foods [6], beverages [7], and vinegar. In the present study, we aimed to isolate bacteria possessing ability to produce higher cellulose from rotten fruits and rotten vegetables. The cellulose producing strains are identified by morphological and biochemical characterization. In the present investigation, we 


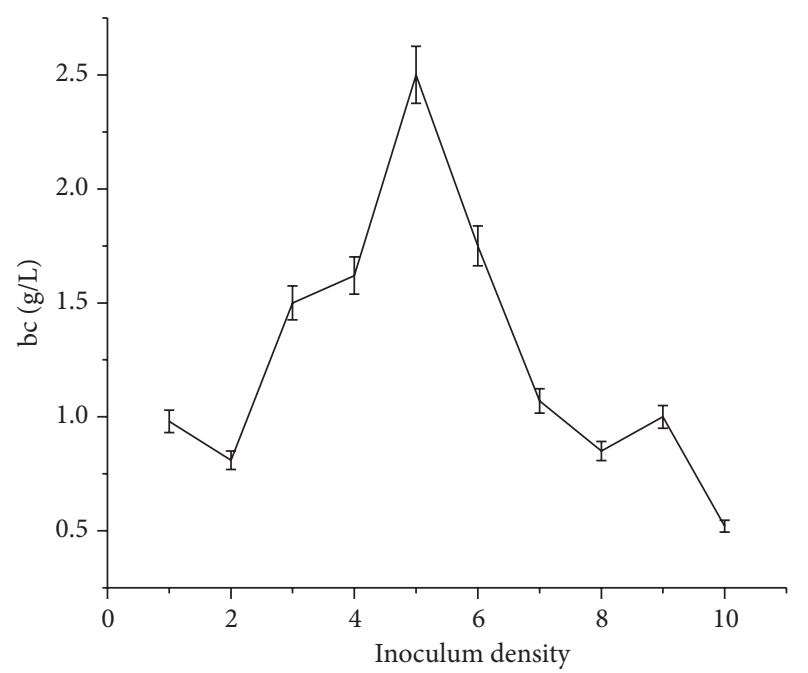

Figure 5: Effect of inoculum size on cellulose production by Gluconacetobacter sp.

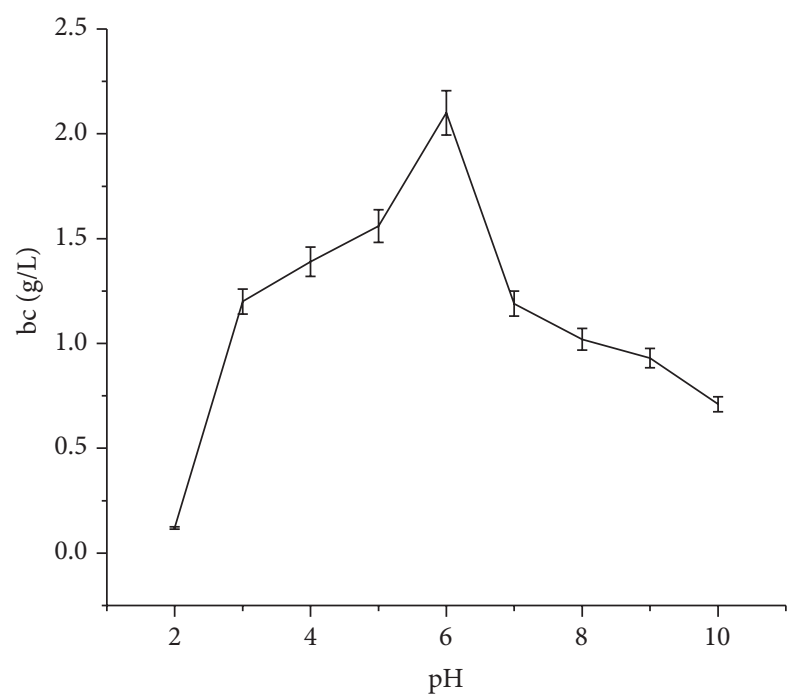

FIGURE 6: Effect of $\mathrm{pH}$ on cellulose production by Gluconacetobacter sp.

report the potent cellulose producer Gluconacetobacter sp. RV28 isolated from rotten pomegranate. The previous studies describe cellulose synthesis as part of primary metabolism which is observed in bacterial species such as Acetobacter xylinum [10], Rhizobium leguminosarum [11, 12], Klebsiella pneumoniae [13], Sarcina ventricle [10], Agrobacterium tumefaciens [14], Salmonella typhimurium [15], Escherichia coli and Enterobacter [2, 15], and cyanobacteria [16]. Schramm and Hestrin identified optimal growth conditions for cellulose production [17]. Similarly in this work several attempts were made to isolate cellulose producer and isolated Pseudomonas sp. RV14, Enterobacter sp. RV11, and Gluconacetobacter sp. RV28. Among all the genera, the Gluconacetobacter genus stands out due to its ability to synthesize and extrude copious amounts of highly pure ribbons of cellulose. In the present study, we isolated most prominent model organism, that

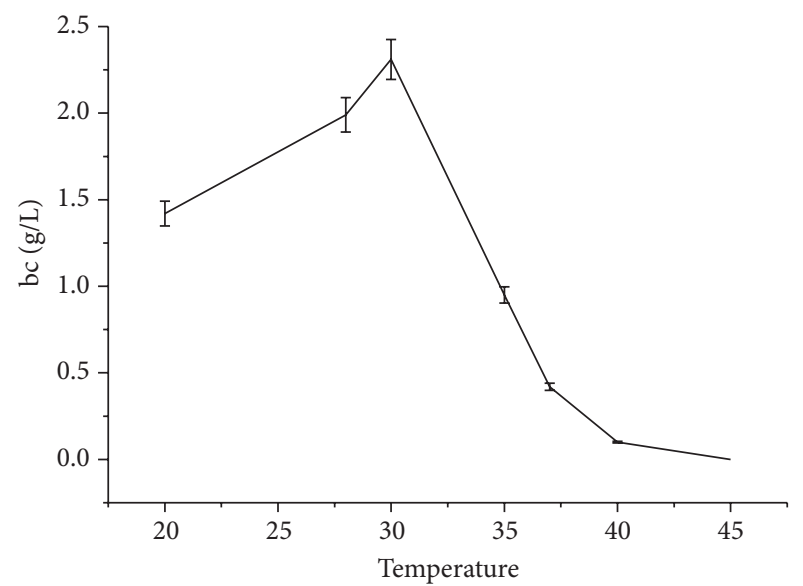

Figure 7: Effect of temperature on cellulose production by Gluconacetobacter $\mathrm{sp}$.

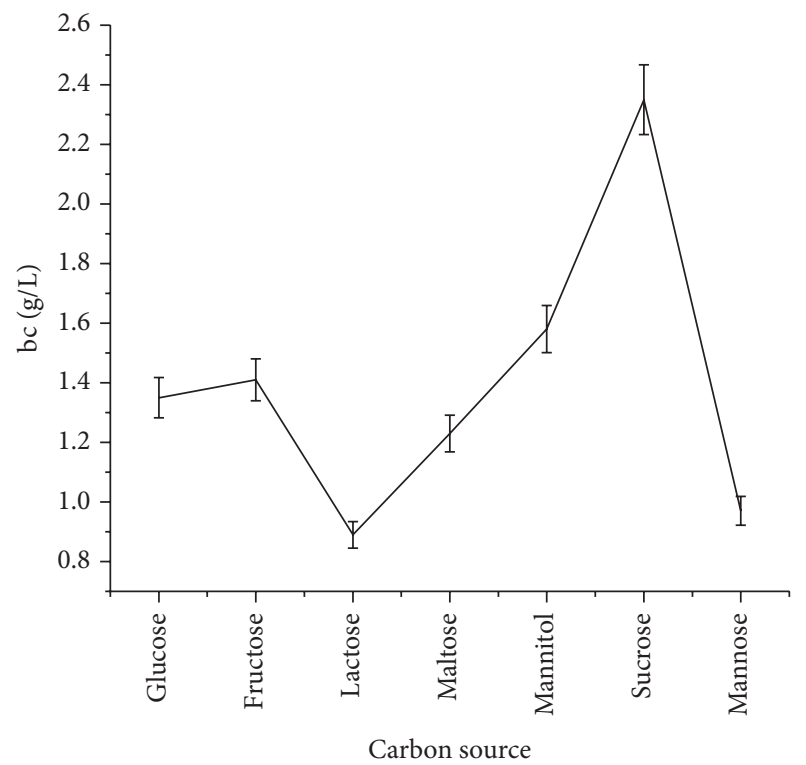

Figure 8: Effect of carbon source on cellulose production by Gluconacetobacter sp.

is, Gluconacetobacter sp. RV28 from rotten pomegranate. The highest yield of $4.7 \mathrm{~g} / \mathrm{L}$ was achieved from the isolate Gluconacetobacter sp. RV28 in optimized medium. Previous studies prove that Acetobacter xylinum a Gram negative, obligate aerobic bacterium has been considered for several years, as an archetype for cellulose synthesis-related studies. A single cell can polymerize 200,000 glucose molecules per second [18], which are extruded in the form of a $100 \mathrm{~nm}$ wide, flat ribbon of cellulose along the longitudinal axis of the cell [19] which remain attached to the cells during cell division [20].

In this study to screen cellulose producing bacteria we added fluorescent brightener dye/calcofluor white in the screening medium. The colonies were observed to be fluorescing when observed under UV light. Calcofluor white present in the screening medium avidly binds to $\beta$-D glucans 


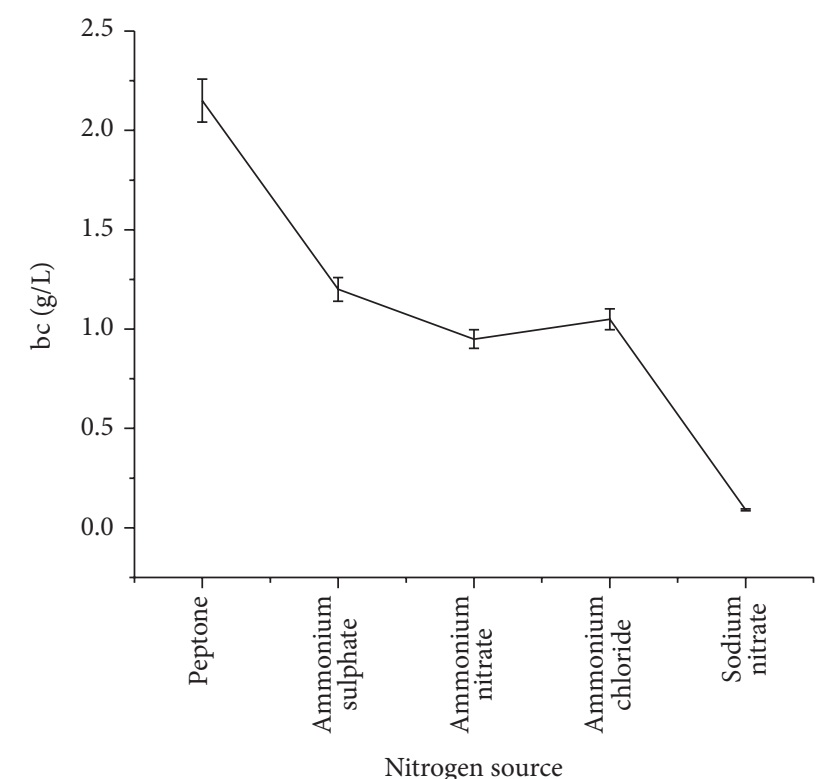

FIGURE 9: Effect of nitrogen source on cellulose production by Gluconacetobacter sp.

in a definable, reversible manner and cellulose producing bacterial colony fluoresces when observed under UV light $[10,21]$.

The cellulose production not only depends on strain but also depends on media ingredients and culture cultivation conditions to achieve highest production. In this study, the effects of different parameters such as inoculum density, $\mathrm{pH}$, temperature, carbon, and nitrogen sources were carried out. The optimized medium contains standard Hestrin and Schramm media, that is, sucrose $2 \%$ and peptone $0.5 \%$ in the presence of yeast extract $0.5 \%$, temperature $30^{\circ} \mathrm{C}, \mathrm{pH} 6$, and inoculum density $5 \%$ resulting in $4.7 \mathrm{~g} / \mathrm{L}$. These results prove that optimization of culture conditions is as important as that of the organism. In the present study, inoculum density cannot be studied by OD method because the strain grown media are almost transparent and pellicle formation at air liquid interphase can be observed within $48 \mathrm{~h}$ of incubation. Many researchers explain that, for maximum cellulose production, the total cell count is not important, and significant point is the number of cell counts in the aerobic zone that are producing cellulose $[22,23]$. Most of the studies describe that the efficiency of cellulose production by Gluconacetobacter is dictated by carbon source availability and the accumulation of metabolic by-products that cause unfavourable growth conditions [1]. Other environmental factors such as temperature, culture type (agitated or static), oxygen diffusion, and $\mathrm{pH}$ also influence cellulose synthesis. The most efficient production of cellulose by Gluconacetobacter sp. occurs under static conditions between $28^{\circ} \mathrm{C}$ and $30^{\circ} \mathrm{C}$ [24].

The Gluconacetobacter sp. can synthesize cellulose from a variety of carbon sources [25]; the most efficient production of cellulose is achieved when glucose is used as the primary carbon source [26]. Different from other carbon sources, glucose can be shuttled directly into the cellulose synthesis pathway [10]. The metabolism of glucose, however, results in the accumulation of gluconate and a concurrent decline in culture $\mathrm{pH}$ [27]. Optimum cellulose synthesis is achieved at a $\mathrm{pH}$ range of 5-6. When the culture $\mathrm{pH}$ falls below 4 as a consequence of gluconate accumulation, cellulose synthesis declines. Once all of the glucose in the media has been oxidized, the bacteria begin to metabolize the gluconate and a gradual increase in culture $\mathrm{pH}$ is observed as the bacteria consume the gluconate. Cellulose synthesis and cell division resume once the $\mathrm{pH}$ levels climb above 4 [1]. Material properties are very important criteria linked to the structure resulting in chemical composition; arrangement of cellulose can be studied by scanning electron microscope. The ultrafine cellulose fibres showed in SEM proved that cellulose produced from Gluconacetobacter sp. RV28 was cellulose microfiber arrangement which in turn proves its water holding capacity. This property was stated by earlier researcher [28].

\section{Conclusions}

The present investigation reported isolation of cellulose producing bacteria from rotten fruit and vegetable samples. The isolates were identified as Pseudomonas sp. RV14, Enterobacter sp. RV11, and Gluconacetobacter sp. RV28. The yield of cellulose with respect to each organism was studied. Under optimum conditions of growth, Gluconacetobacter sp. RV28 achieved highest cellulose yield of $4.7 \mathrm{~g} / \mathrm{L}$. The bacterial cellulose harvested from this organism showed ultrafine microfibrils in scanning electron micrographs. These findings are significant for the continual improvement of cellulose synthesis by Gluconacetobacter sp. RV28 with future implications of bioengineering to produce cellulose on an industrial scale.

\section{Conflict of Interests}

The authors declare that there is no conflict of interests regarding the publication of this paper.

\section{Acknowledgments}

Authors are thankful to the management of Bapuji Institute of Engineering and Technology, Davangere, for supporting the research work. Dr. B. E. Rangaswamy and K. P. Vanitha sincerely thank Department of Science and Technology, New Delhi, for providing financial assistance under Women Scientist Scheme-A, (File number SR/WOS-A/LS-432/2011). Authors also thank Sophisticated Test and Instrumentation Centre, Cochin University of Science \& Technology, Cochin, Kerala, for providing SEM analysis.

\section{References}

[1] P. R. Chawla, I. B. Bajaj, S. A. Survase, and R. S. Singhal, "Microbial cellulose: fermentative production and applications," Food Technology and Biotechnology, vol. 47, no. 2, pp. 107-124, 2009. 
[2] B. S. Hungund and S. G. Gupta, "Production of bacterial cellulose from Enterobacter amnigenus GH-1 isolated from rotten apple," World Journal of Microbiology and Biotechnology, vol. 26, no. 10, pp. 1823-1828, 2010.

[3] S. Yamanaka, K. Watanabe, N. Kitamura et al., "The structure and mechanical properties of sheets prepared from bacterial cellulose," Journal of Materials Science, vol. 24, no. 9, pp. 31413145, 1989.

[4] R. E. Cannon and S. M. Anderson, "Biogenesis of bacterial cellulose," Critical Reviews in Microbiology, vol. 17, no. 6, pp. 435-447, 1991.

[5] F. Dellaglio, I. Cleenwerck, G. E. Felis, K. Engelbeen, D. Janssens, and M. Marzotto, "Description of Gluconacetobacter swingsii sp. nov. and Gluconacetobacter rhaeticus sp. nov., isolated from Italian apple fruit," International Journal of Systematic and Evolutionary Microbiology, vol. 55, no. 6, pp. 2365-2370, 2005.

[6] J. K. Park, Y. H. Park, and J. Y. Jung, "Production of bacterial cellulose by Gluconacetobacter hansenif PJK isolated from rotten apple," Biotechnology and Bioprocess Engineering, vol. 8, no. 2, pp. 83-88, 2003.

[7] S. Jia, H. Ou, G. Chen et al., "Cellulose production from Gluconobacter oxydans TQ-B2," Biotechnology and Bioprocess Engineering, vol. 9, no. 3, pp. 166-170, 2004.

[8] S. Bielecki, A. Krystynowicz, M. Turkiewicz, and H. Kalinowska, "Bacterial cellulose," in Biopolymers Online, pp. 37-46, Wiley Online Library, 2005.

[9] J. G. Holt, N. R. Krieg, P. H. Sneath, J. T. Staley, and S. T. Williams, Bergey's Manual of Determinative Bacteriology, 9th edition, 2004.

[10] P. Ross, R. Mayer, and M. Benziman, "Cellulose biosynthesis and function in bacteria," Microbiological Reviews, vol. 55, no. 1, pp. 35-58, 1991.

[11] H. Kitagawa, M. Kanamori, S. Tatezaki, T. Itoh, and H. Tsuji, "Multiple spinal ossified arachnoiditis-a case report," Spine, vol. 15, no. 11, pp. 1236-1238, 1990.

[12] T. Mukai, T. Toba, T. Itoh, and S. Adachi, "Structural investigation of the capsular polysaccharide from Lactobacillus kefiranofaciens $\mathrm{K}_{1}$," Carbohydrate Research, vol. 204, pp. 227232, 1990.

[13] M. Nomura, H. Harino, and T. Itoh, "Anomalous change in temperature during the pressure-induced phase transition of KI," Japanese Journal of Applied Physics, vol. 29, no. 11, pp. 24562459, 1990.

[14] A. G. Matthysse, S. White, and R. Lightfoot, "Genes required for cellulose synthesis in Agrobacterium tumefaciens," Journal of Bacteriology, vol. 177, no. 4, pp. 1069-1075, 1995.

[15] Y. Hatta, M. Baba, and S. Aizawa, "Changes of pulmonaryfunction in patients treated with bone-marrow transplantation after total-body irradiation," Acta Haematologica Japonica, vol. 53, no. 6, pp. 923-930, 1990.

[16] T. K. Ayaki, K. Fujikawa, H. Ryo, T. Itoh, and S. Kondo, "Induced rates of mitotic crossing over and possible mitotic gene conversion per wing anlage cell in Drosophila melanogaster by X rays and fission neutrons," Genetics, vol. 126, no. 1, pp. 157$166,1990$.

[17] M. Schramm and S. Hestrin, "Factors affecting production of cellulose at the air/liquid interface of a culture of Acetobacter xylinum," Journal of General Microbiology, vol. 11, no. 1, pp. 123129, 1954.
[18] S. Hestrin and M. Schramm, "Synthesis of cellulose by Acetobacter xylinum. 2. Preparation of freeze-dried cells capable of polymerizing glucose to cellulose," Biochemical Journal, vol. 58, no. 2, pp. 345-352, 1954.

[19] R. M. Brown Jr., J. H. M. Willison, and C. L. Richardson, "Cellulose biosynthesis in Acetobacter xylinum: visualization of the site of synthesis and direct measurement of the in vivo process," Proceedings of the National Academy of Sciences of the United States of America, vol. 73, no. 12, pp. 4565-4569, 1976.

[20] M. Marx-Figini, "The control of molecular weight and molecular weight distribution," in Cellulose and Other Natural Polymer Systems, R. M. Jr. Brown, Ed., pp. 243-271, Plenum Publishing, New York, NY, USA, 1982.

[21] B. S. Hungund and S. G. Gupta, "Improved production of bacterial cellulose from Gluconacetobacter persimmonis GH-2," Journal of Microbial and Biochemical Technology, vol. 2, no. 5, pp. 127-133, 2010.

[22] M. Hornung, M. Ludwig, A. M. Gerrard, and H.-P. Schmauder, "Optimizing the production of bacterial cellulose in surface culture: evaluation of substrate mass transfer influences on the bioreaction (part 1)," Engineering in Life Sciences, vol. 6, no. 6, pp. 537-545, 2006.

[23] F. Jahan, V. Kumar, G. Rawat, and R. K. Saxena, "Production of microbial cellulose by a bacterium isolated from fruit," Applied Biochemistry and Biotechnology, vol. 167, no. 5, pp. 1157-1171, 2012.

[24] Z. Gromet, M. Schramm, and S. Hestrin, "Synthesis of cellulose by Acetobacter xylinum," Journal of Fermentation and Bioengineering, vol. 75, pp. 18-22, 1957.

[25] S. Masaoka, T. Ohe, and N. Sakota, "Production of cellulose from glucose by Acetobacter xylinum," Journal of Fermentation and Bioengineering, vol. 75, no. 1, pp. 18-22, 1993.

[26] K. V. Ramana, A. Tomar, and L. Singh, "Effect of various carbon and nitrogen sources on cellulose synthesis by Acetobacter xylinum," World Journal of Microbiology and Biotechnology, vol. 16, no. 3, pp. 245-248, 2000.

[27] S. Keshk and K. Sameshima, "Influence of lignosulfonate on crystal structure and productivity of bacterial cellulose in a static culture," Enzyme and Microbial Technology, vol. 40, no. 1, pp. 4-8, 2006.

[28] D. Lin, P. Lopez-Sanchez, R. Li, and Z. Li, "Production of bacterial cellulose by Gluconacetobacter hansenii CGMCC 3917 using only waste beer yeast as nutrient source," Bioresource Technology, vol. 151, pp. 113-119, 2014. 

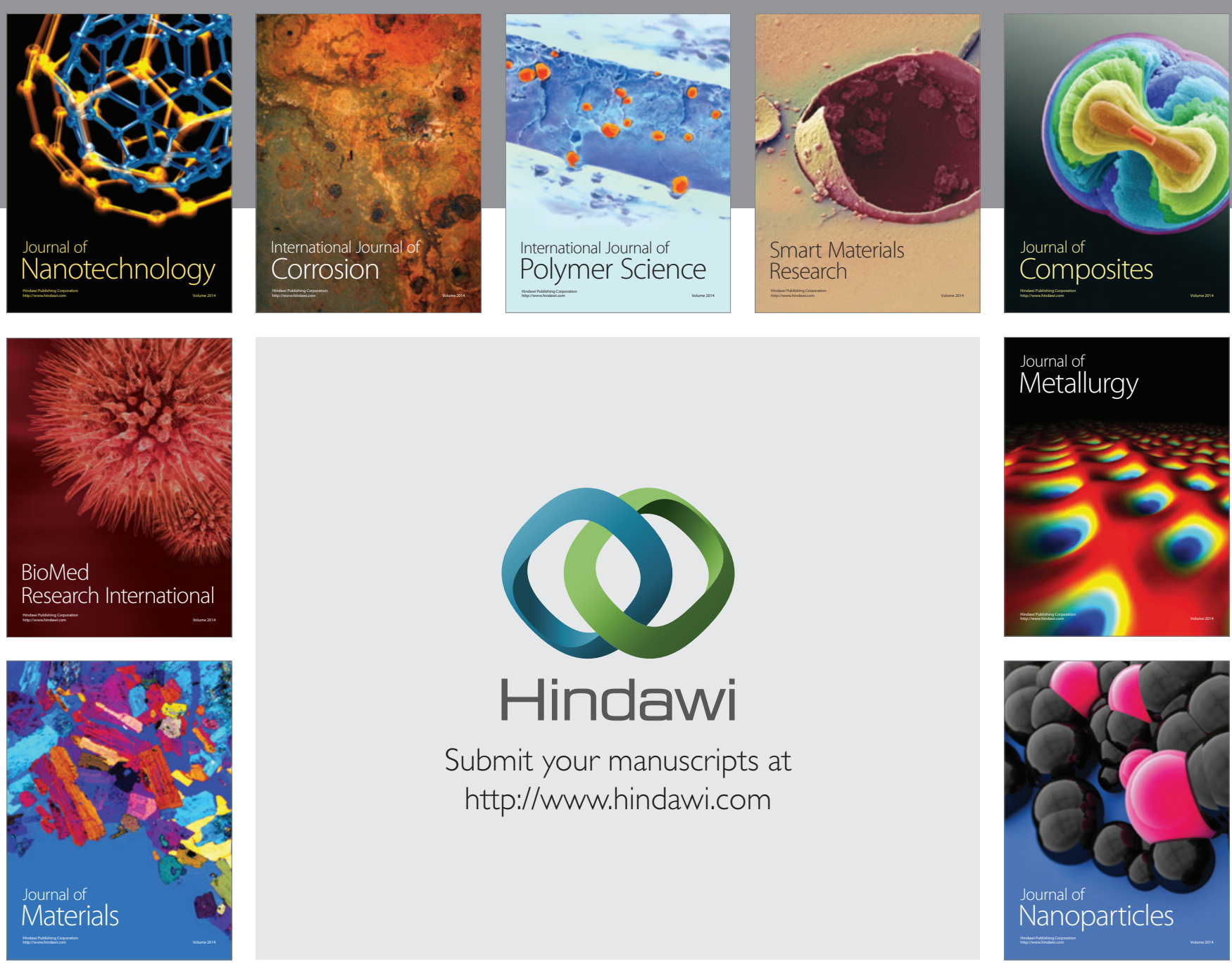

Submit your manuscripts at http://www.hindawi.com
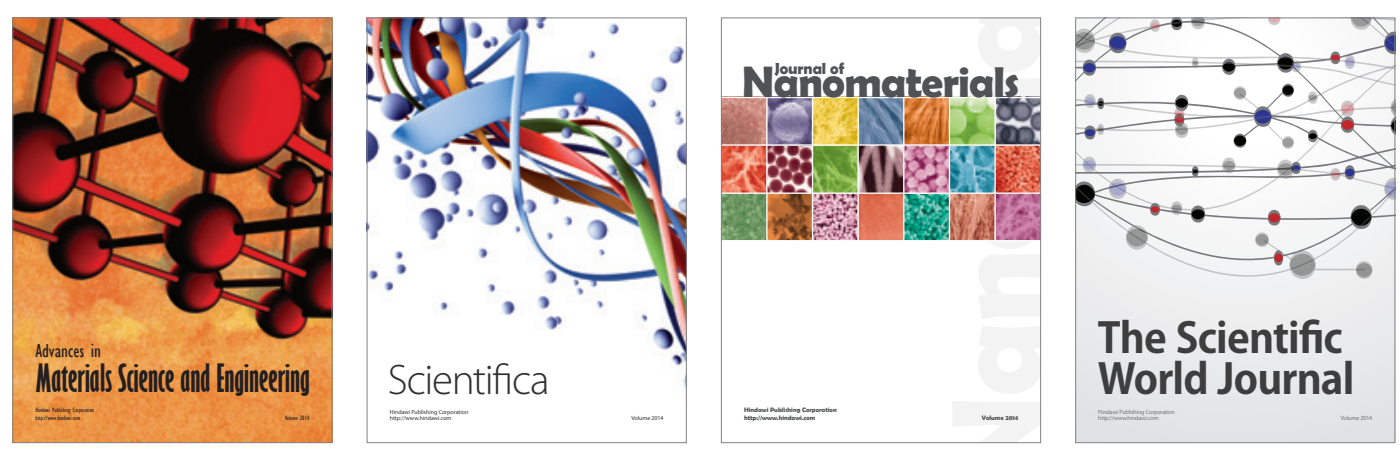

\section{The Scientific World Journal}
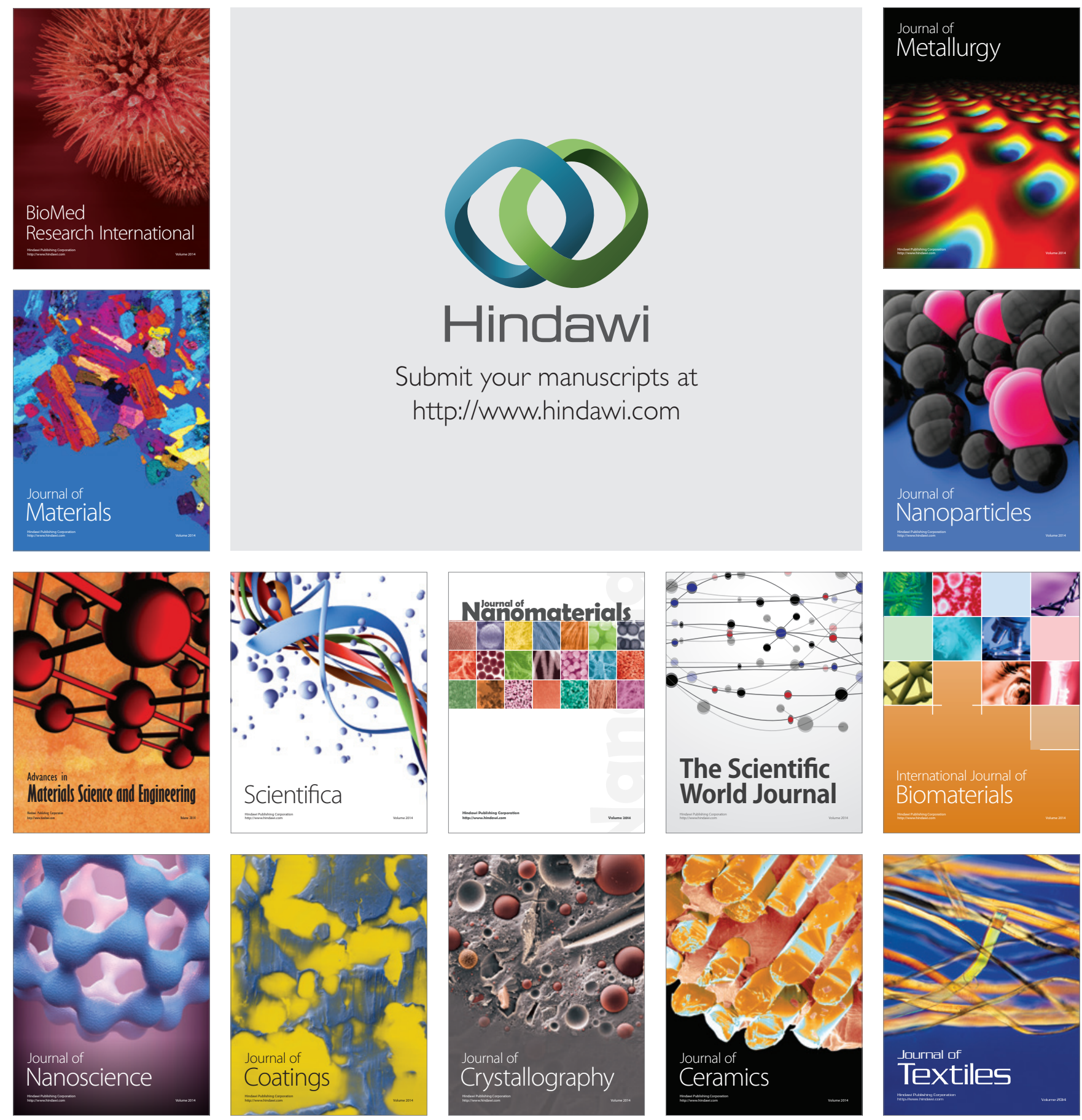